\title{
Impact of Temperature on Low-Cycle Fatigue Characteristics of the HR6W Alloy
}

\author{
Grzegorz Junak $^{1, *}$, Anżelina Marek ${ }^{1}$ and Michał Paduchowicz ${ }^{2}$ \\ 1 Faculty of Materials Engineering, Silesian University of Technology, 40-019 Katowice, Poland; \\ anzelina.marek@polsl.pl \\ 2 Faculty of Mechanical Engineering, Wrocław University of Science and Technology, 50-370 Wrocław, Poland; \\ michal.paduchowicz@pwr.edu.pl \\ * Correspondence: grzegorz.junak@polsl.pl
}

Citation: Junak, G.; Marek, A.;

Paduchowicz, M. Impact of

Temperature on Low-Cycle Fatigue

Characteristics of the HR6W Alloy.

Materials 2021, 14, 6741. https://

doi.org/10.3390/ma14226741

Academic Editors: Rui

Miranda Guedes and

Davide Palumbo

Received: 31 August 2021

Accepted: 3 November 2021

Published: 9 November 2021

Publisher's Note: MDPI stays neutral with regard to jurisdictional claims in published maps and institutional affiliations.

Copyright: (c) 2021 by the authors. Licensee MDPI, Basel, Switzerland. This article is an open access article distributed under the terms and conditions of the Creative Commons Attribution (CC BY) license (https:/ / creativecommons.org/licenses/by/ $4.0 /)$.

\begin{abstract}
This paper presents the results of tests conducted on the HR6W (23Cr-45Ni-6W-Nb-Ti-B) alloy under low-cycle fatigue at room temperature and at $650^{\circ} \mathrm{C}$. Fatigue tests were carried out at constant values of the total strain ranges. The alloy under low-cycle fatigue showed cyclic strengthening both at room temperature and at $650{ }^{\circ} \mathrm{C}$. The degree of $\mathrm{HR} 6 \mathrm{~W}$ strengthening described by coefficient $\mathrm{n}^{\prime}$ was higher at higher temperatures. At the same time, its fatigue life $\mathrm{N}_{\mathrm{f}}$ at room temperature was, depending on the range of total strain adopted in the tests, several times higher than observed at $650{ }^{\circ} \mathrm{C}$.
\end{abstract}

Keywords: HR6W alloy; low-cycle fatigue; cyclic strengthening curve; fatigue life

\section{Introduction}

In Poland, electricity is mainly produced in conventional power plants, i.e., those in which the steam needed to drive the generators comes from coal-fired or lignite-fired boilers. These power plants emit significant amounts of $\mathrm{CO}_{2}$ to the atmosphere. With European policy aiming to reduce $\mathrm{CO}_{2}$ emissions into the atmosphere, the Polish energy sector needs to adapt to European regulations. The reduction in $\mathrm{CO}_{2}$ emissions can be achieved, among others, by increasing the operating parameters of supercritical boilers with constantly improved advanced materials which have better properties at elevated temperatures [1-7]. Such materials include the HR6W alloy, which is mainly used for superheater tubes in power boilers, thick-walled tubular elements, reactors, as well as in chemical plants.

What is required from materials under high temperatures and pressures, which occur in boilers under increased operating parameters, is high creep resistance and thermalmechanical and low-cycle fatigue resistance as well as high corrosion resistance [1-22]. Unfortunately, in contrast to the large number of generally available data in the field of research on basic mechanical properties at room temperature and elevated temperature, creep, and corrosion resistance of the HR6W alloy [1-13,15-19], there is less data on thermomechanical and low-cycle fatigue testing of this alloy $[2,6,14,20]$. The benefits of using data obtained in low-cycle fatigue tests at elevated temperature for prediction of durability under thermo-mechanical fatigue loading for the HR6W alloy were demonstrated by Noguchi et al. [20]. The authors of the paper [20] investigated the relationship between the fatigue life of HR6W in isothermal fatigue tests and the fatigue life obtained in thermomechanical fatigue tests. The tests were carried out in the temperature range between 100 and $700{ }^{\circ} \mathrm{C}$. Researchers pointed out a similarity between these types of tests for this alloy. Therefore, it seems justified to estimate the strength of the alloy under thermomechanical fatigue based on less complex, more feasible isothermal fatigue tests. In the work presented, a study of low-cycle fatigue at room temperature and at $650{ }^{\circ} \mathrm{C}$ constituted a primary research experiment. This research is meant as a contribution to the existing 
knowledge on the cyclic behavior of the HR6W alloy with the properties determined at $650{ }^{\circ} \mathrm{C}$. Therefore, the test results obtained can be useful for more precise forecasting of the fatigue life of power plant components.

\section{Materials and Methods}

The material for low-cycle fatigue testing was the as-delivered HR6W (23Cr-45Ni-6W$\mathrm{Nb}$-Ti-B) alloy taken from a fragment of a thick-walled pipe. The chemical composition of the alloy was determined on the basis of the X-ray energy spectrum as presented in Figure 1a. A microanalysis of the chemical composition of the alloy was performed using the EDS Oxford LINK ISIS-300 X-ray (Manufacture: Oxford Instruments plc) microanalyzer coupled with a JEOL JSM 5800 LV scanning electron microscope (Manufacture: Oxford Instruments plc).

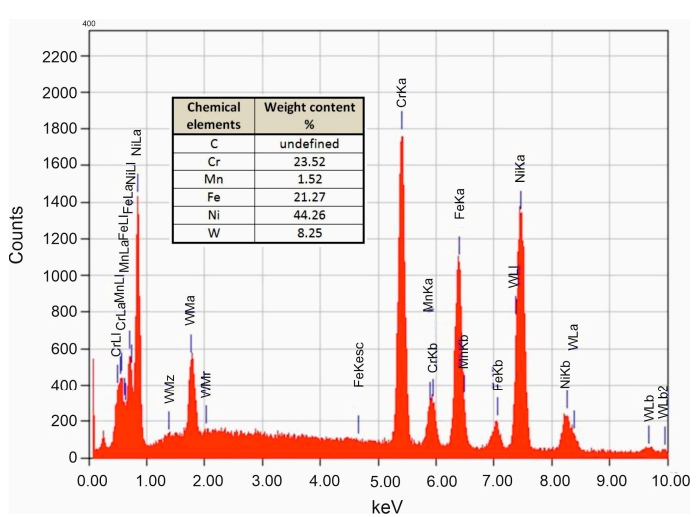

(a)

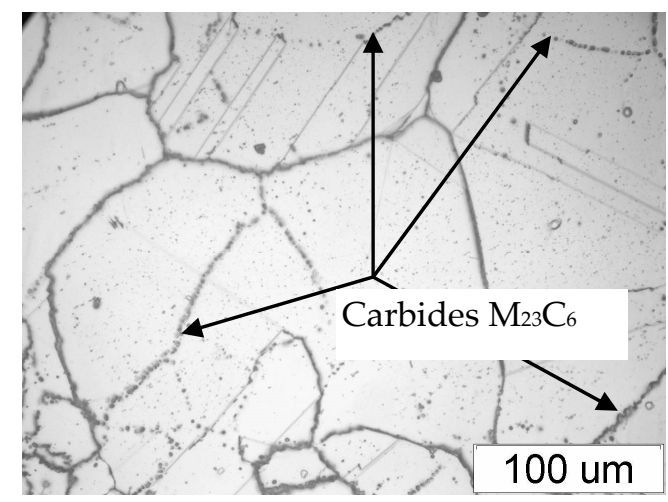

(b)

Figure 1. SEM. X-ray energy spectrum of the as-delivered HR6W (a); microstructure of the as-delivered HR6W alloy (b).

In the as-delivered condition, the material has an austenite structure, which is characterized by a non-uniform grain size. Numerous precipitations of $\mathrm{M}_{23} \mathrm{C}_{6}$ carbides were observed at the grain boundaries (Figure $1 b$ ).

Fatigue test samples (Figure 2) were made of material taken from the $\$ 360 \mathrm{~mm} \times$ $75 \mathrm{~mm}$ pipe.

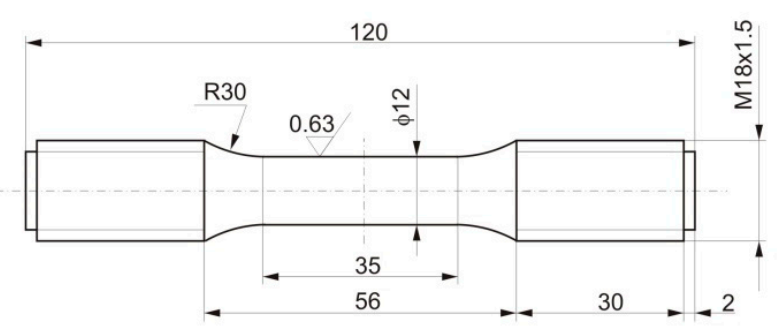

Figure 2. Dimensions in millimeters of a HR6W sample for low-cycle fatigue testing.

Mechanical properties were tested at room temperature and at $650{ }^{\circ} \mathrm{C}$. The test results are presented in Table 1.

Table 1. Mechanical properties of the HR6W alloy obtained at room temperature and $650{ }^{\circ} \mathrm{C}$.

\begin{tabular}{ccccc}
\hline Mechanical Properties & YS & UTS & $\begin{array}{c}\text { A } \\
\mathbf{\%}\end{array}$ & $\begin{array}{c}\text { Z } \\
\mathbf{\%}\end{array}$ \\
\hline Room temperature & 271 & 624 & 59 & 49 \\
$650^{\circ} \mathrm{C}$ & 146 & 431 & 70 & 52 \\
\hline
\end{tabular}


Fatigue tests for the low-cycle HR6W alloy were carried out on the MTS-810 testing machine (Figure 3). The tests were run in strain control (extensometer MTS-632-11C-20 temp. room, extensometer MTS-632-14B-05 temp. $650^{\circ} \mathrm{C}$ ). Sinusoidal loading cycles were applied with a cycle asymmetry ratio $\mathrm{R}=-1$ and load frequency $\mathrm{f}=0.1 \mathrm{~Hz}$. The fatigue tests were carried out at room temperature and at $650{ }^{\circ} \mathrm{C}$. The tests were carried out for five ranges of total deformation $\Delta \varepsilon_{\mathrm{t}}=0.6 ; 0.7 ; 0.8 ; 1.0$ and $1.2 \%$. The samples were induction heated using a Hüttinger TIG-300 heater (Figure 4). Low-cycle fatigue tests at elevated temperatures were carried out with the use of a FLIR SC6000 thermal imaging camera, which allowed continuous temperature control during the tests.

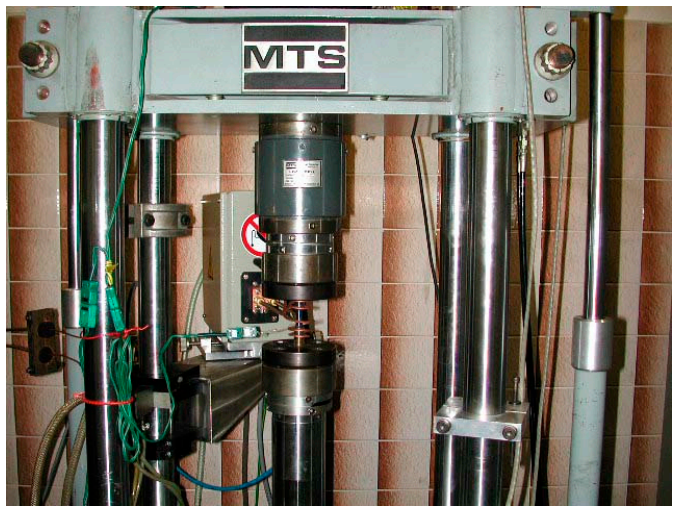

Figure 3. MTS-810 testing machine used in low-cycle testing.

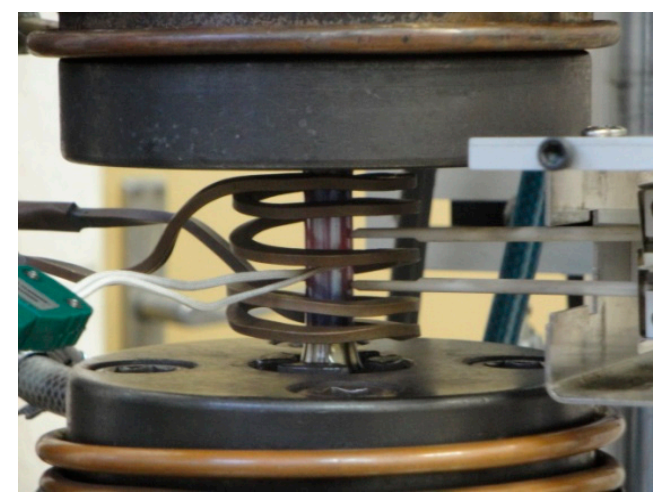

Figure 4. Testing station for low-cycle fatigue tests at $650{ }^{\circ} \mathrm{C}$.

\section{Results and Discussion}

During the fatigue tests, changes in stress amplitude $\left(\sigma_{a n}\right)$ and strain $\left(\varepsilon_{t}\right)$ versus the number of cycles $(\mathrm{N})$ were constantly recorded. On this basis, hysteresis loops characteristic for selected stages of the fatigue process were developed, i.e., the initial phase, the saturation phase (characterized by a fixed value of the stress amplitude $\sigma_{\mathrm{an}}$ ), and the fracture phase for the sample. Examples of such graphs for the selected strain range $\Delta \varepsilon_{t}=0.6 \%$ are shown in Figures 5 and 6. In low-cycle tests, fatigue life $\mathrm{N}_{\mathrm{f}}$ was defined as the number of cycles to failure for the sample. 


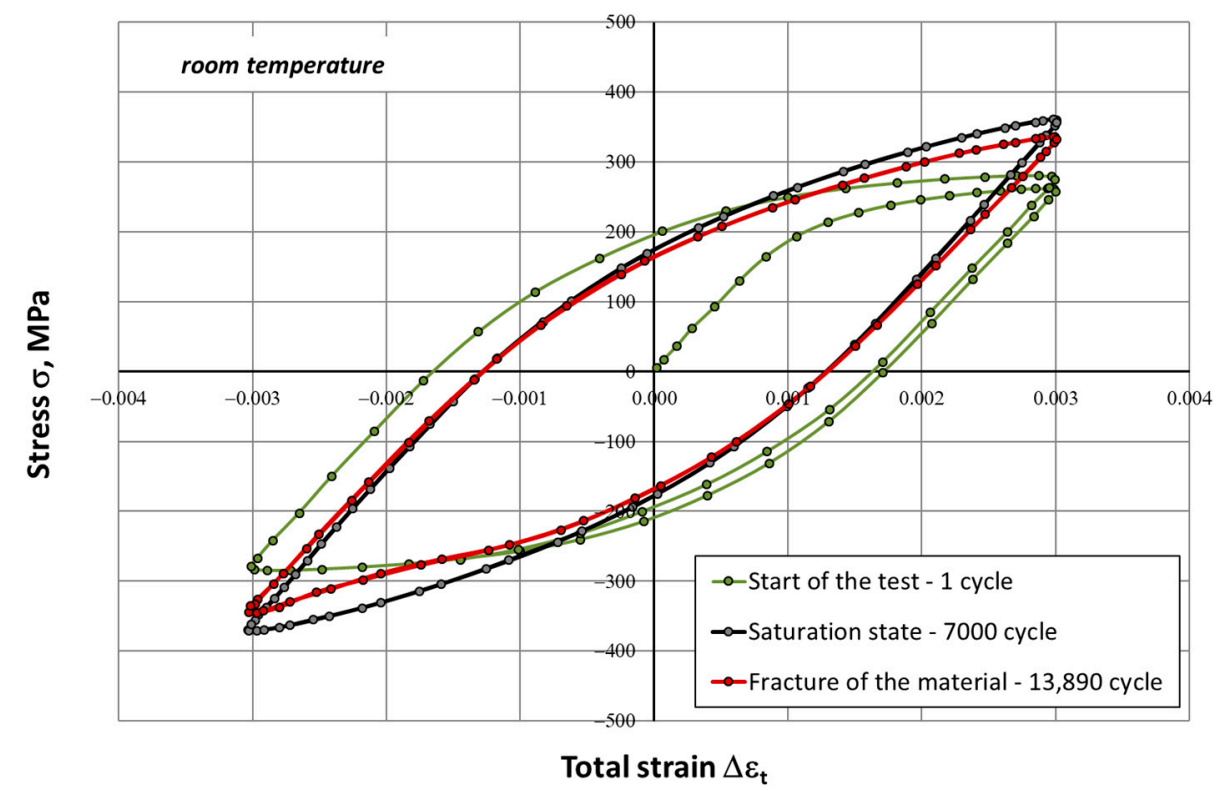

Figure 5. Hysteresis loops determined in a low-cycle fatigue test at room temperature for the strain range $\Delta \varepsilon_{\mathrm{t}}=0.6 \%$.

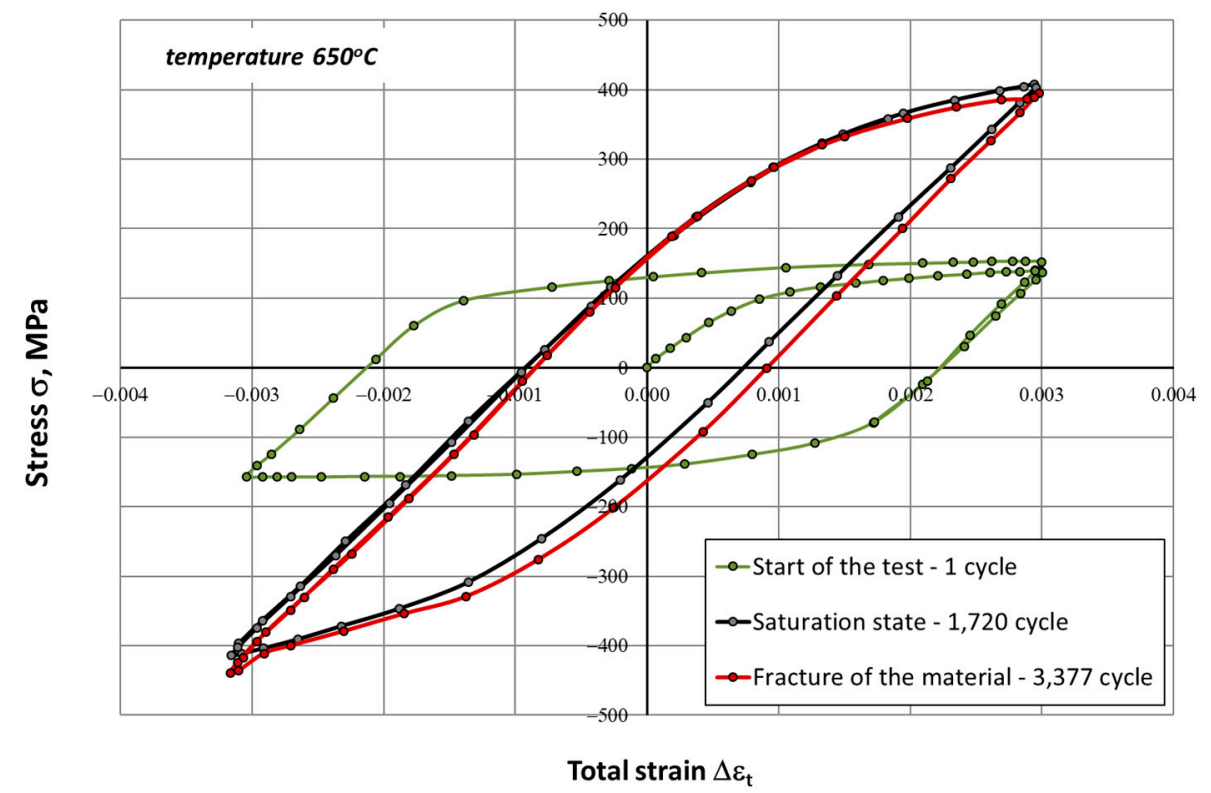

Figure 6. Hysteresis loops determined in a low-cycle fatigue test at $650{ }^{\circ} \mathrm{C}$ for the strain range $\Delta \varepsilon_{\mathrm{t}}=0.6 \%$.

The process of cyclic hardening of the HR6W alloy is clearly visible in the above hysteresis loops obtained in low-cycle fatigue tests at room temperature and at elevated temperature $\left(650{ }^{\circ} \mathrm{C}\right)$ for the total strain range of $0.6 \%$. It is manifested in an increase between the stress values read at the tops of the hysteresis loop corresponding to the beginning of the test and the saturation state. A particularly notable amplification occurs for samples tested at $650{ }^{\circ} \mathrm{C}$, where the stress value increases more than twice, from a level of about $160 \mathrm{MPa}$ for the initial loop to $400 \mathrm{MPa}$ corresponding to the saturation loop. Moreover, the saturation stresses recorded in the tests carried out at $650{ }^{\circ} \mathrm{C}$ were higher than those recorded at room temperature (Figure $7 \mathrm{~b}$ ). 


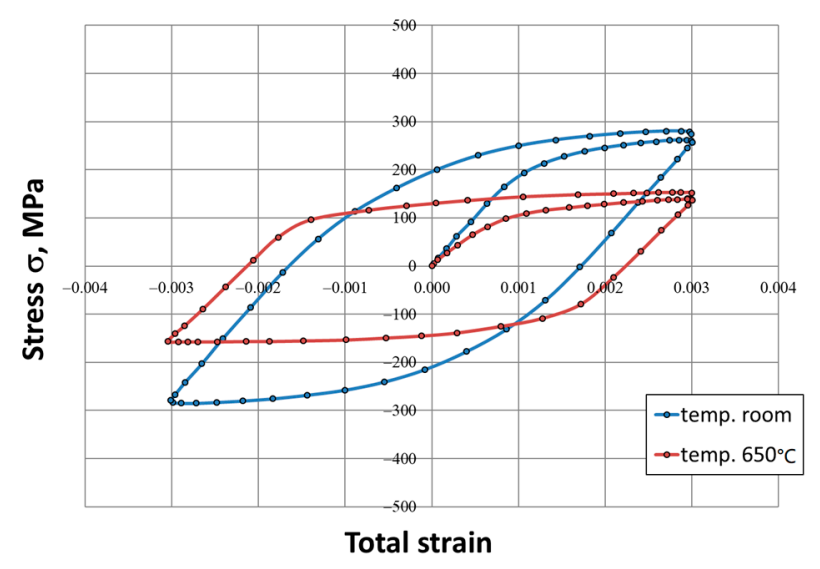

(a)

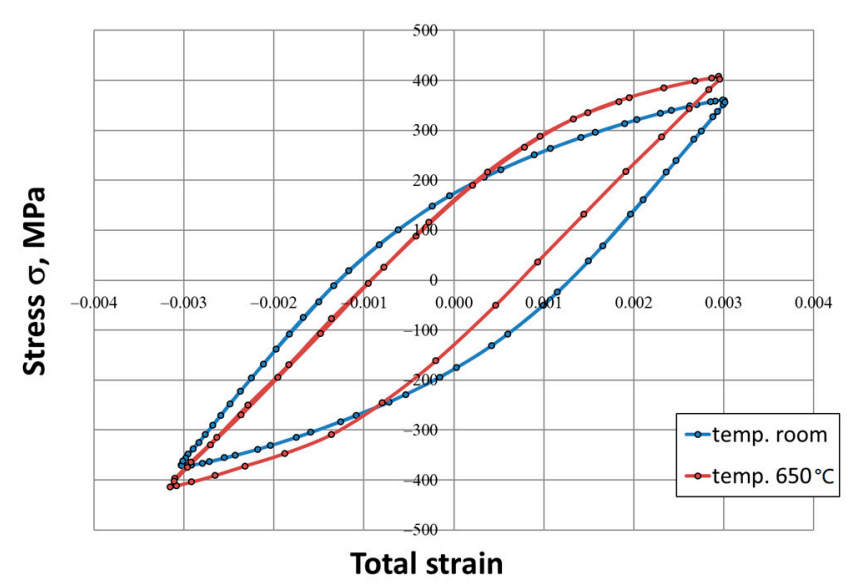

(b)

Figure 7. Comparison of the hysteresis loops determined in the low-cycle fatigue test at room temperature and at $650{ }^{\circ} \mathrm{C}$ for the strain range $\Delta \varepsilon_{\mathrm{t}}=0.6 \%$ : initial state-(a), saturation state-(b).

Both at room temperature and at elevated temperature, a distinct change in the shape of the hysteresis loop was observed (Figures 5-7), which is linked directly with material hardening in the process of cyclic deformation. The shape and the dimensions of the hysteresis loop indicated a very large increase in the maximum and the minimum stress. This was especially evident at elevated temperature $\left(650^{\circ} \mathrm{C}\right)$. Cyclic plastic strains occurring in the internal structure of the material may also cause different stress states in differentlyoriented grains. This can trigger plastic deformation mechanisms, which results in the Bauschinger effect. This effect is caused by both mechanical strengthening, presumably related to the reconstruction of dislocation systems and the increase in their density, as well as to the precipitation processes caused by prolonged exposure to elevated temperature.

Such behavior of the HR6W alloy is linked to precipitation strengthening occurring at its grain boundaries, responsible for blocking the slip bands. In the case of this alloy, precipitation processes are intensified as a result of high temperatures. Therefore, in order to determine the reasons for the hardening of the HR6W alloy at $650{ }^{\circ} \mathrm{C}$, metallographic tests of the material taken from the samples submitted to the low-cycle fatigue tests were carried out.

It can also be seen that the maximum stress in the first load cycle at room temperature is higher than the maximum stress in the first cycle at $650{ }^{\circ} \mathrm{C}$. This behavior of the material which differs in the saturated state in relation to the first load cycle results from the simultaneous impact of the temperature and the number of load cycles on the strengthening process. On the one hand, an increased temperature affects the weakening of the material; on the other hand, its long-term effect favors precipitation processes that lead to strengthening [12].

The changed behavior of the material in the saturated state results from the simultaneous influence of the temperature and the number of load cycles on the material strengthening process. On the one hand, the increase in temperature affects the weakening of the material, yet, on the other, its long-term effect favors precipitation processes, thus leading to the strengthening of the material.

Figures 8 and 9 present the metallographic structures obtained for the samples under observation. 


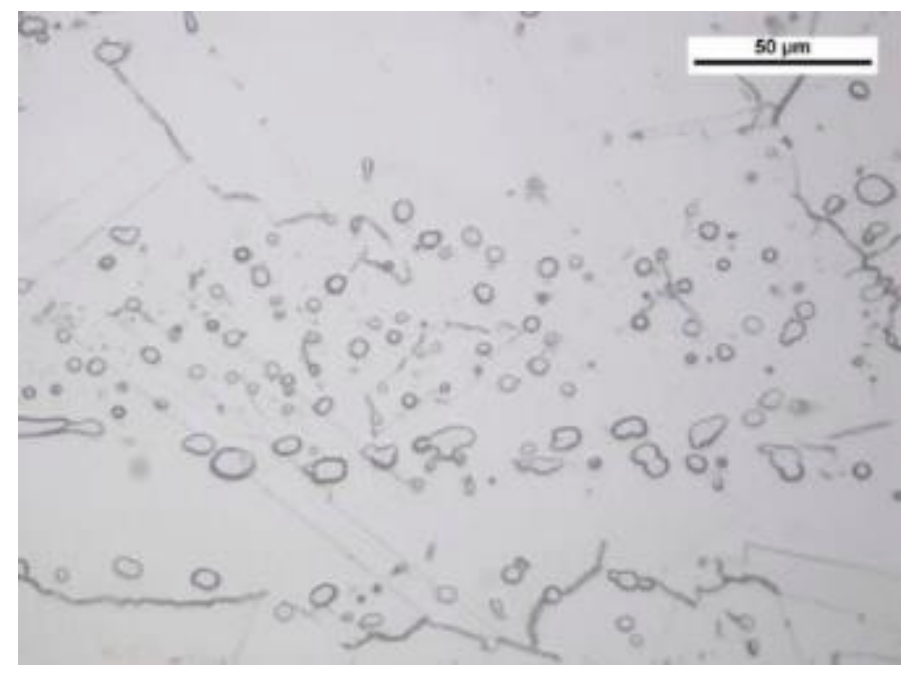

Figure 8. High-nickel austenite with banded carbide precipitates $\mathrm{M}_{23} \mathrm{C}_{6}$. Light microscopy. Mi30Fe, a sample material subjected to a total strain of $0.6 \%$ at $650{ }^{\circ} \mathrm{C}$, was etched.

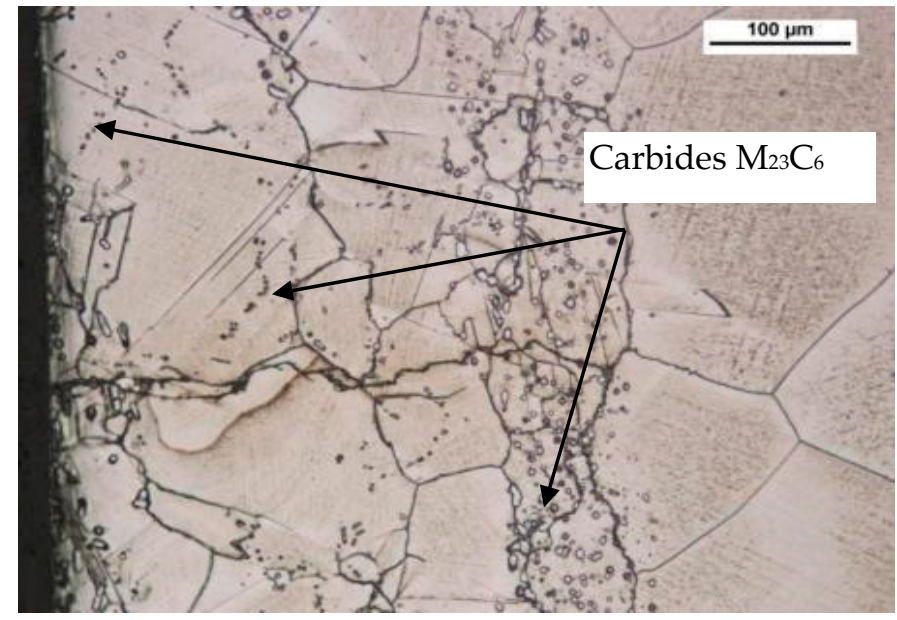

Figure 9. Microstructure of the HR6W alloy. Light microscopy Mi30Fe, a sample material subjected to a total strain of $0.7 \%$ at $650{ }^{\circ} \mathrm{C}$, was etched.

Based on the analysis of the obtained specimens, coarse-grained, high-nickel austenite with visible twins and streaked precipitates of carbides $\mathrm{M}_{23} \mathrm{C}_{6}$ was found. These precipitates were distributed in the direction of plastic forming. Carbides $\mathrm{M}_{23} \mathrm{C}_{6}$ distributed on the boundaries of austenite grains create a local continuous shells. In addition, this alloy was shown to form both MC carbides. All these structural precipitates are in turn responsible for such strong strengthening of the HR6W material as observed in low-cycle fatigue testing at elevated temperature.

The mechanical characteristics of HR6W determined in the low-cycle fatigue tests at room temperature and elevated temperature are summarized in Tables 2 and 3. Based on these data, cyclic stress-strain curves for this alloy were plotted as presented in Figures 10 and 11, which were described by a mathematical model in the form of $\sigma_{\mathrm{an}}=\mathrm{A} \cdot \varepsilon_{\mathrm{ac}}{ }^{\mathrm{b}}$ and coupled with a curve determined in the static tensile test. 
Table 2. Mechanical characteristics of HR6W alloy determined in low-cycle fatigue testing at room temperature.

\begin{tabular}{ccccc}
\hline$\Delta \varepsilon_{\mathrm{t}}, \%$ & $\boldsymbol{\varepsilon}_{\text {ael }}$ & $\boldsymbol{\varepsilon}_{\text {apl }}$ & $\boldsymbol{\sigma}_{\text {an }}, \mathbf{M P a}$ & $\mathbf{N}_{\mathbf{f}}$ \\
\hline 0.6 & 0.0016 & 0.0014 & 362.6 & 13,890 \\
0.7 & 0.0019 & 0.0016 & 388.4 & 10,220 \\
0.8 & 0.0019 & 0.0021 & 395.3 & 5358 \\
1.0 & 0.0020 & 0.0030 & 402.9 & 3250 \\
1.2 & 0.0022 & 0.0038 & 409.7 & 2630 \\
\hline
\end{tabular}

where $\varepsilon_{\text {ael }}$-elastic strain amplitude, $\varepsilon_{\text {apl }}$-plastic strain amplitude, $\sigma_{\text {an }}$-saturation stress amplitude, $\mathrm{N}_{\mathrm{f}}$-fatigue life as the number of cycles to fracture.

Table 3. Mechanical characteristics of HR6W alloy determined in low-cycle fatigue tests at $650{ }^{\circ} \mathrm{C}$.

\begin{tabular}{ccccc}
\hline$\Delta \varepsilon_{\mathbf{t}}, \%$ & $\varepsilon_{\text {ael }}$ & $\varepsilon_{\text {apl }}$ & $\sigma_{\text {an, }} \mathbf{M P a}$ & $\mathbf{N}_{\mathbf{f}}$ \\
\hline 0.6 & 0.00214 & 0.00086 & 412.3 & 3377 \\
0.7 & 0.00238 & 0.00112 & 449.2 & 2179 \\
0.8 & 0.00263 & 0.00137 & 454.5 & 1662 \\
1.0 & 0.00284 & 0.00216 & 478.0 & 1047 \\
1.2 & 0.00354 & 0.00246 & 497.6 & 834
\end{tabular}

where $\varepsilon_{\text {ael }}$-elastic strain amplitude, $\varepsilon_{\text {apl }}$-plastic strain amplitude, $\sigma_{\text {an }}$-saturation stress amplitude, $\mathrm{N}_{\mathrm{f}}$-fatigue life as the number of cycles to fracture.

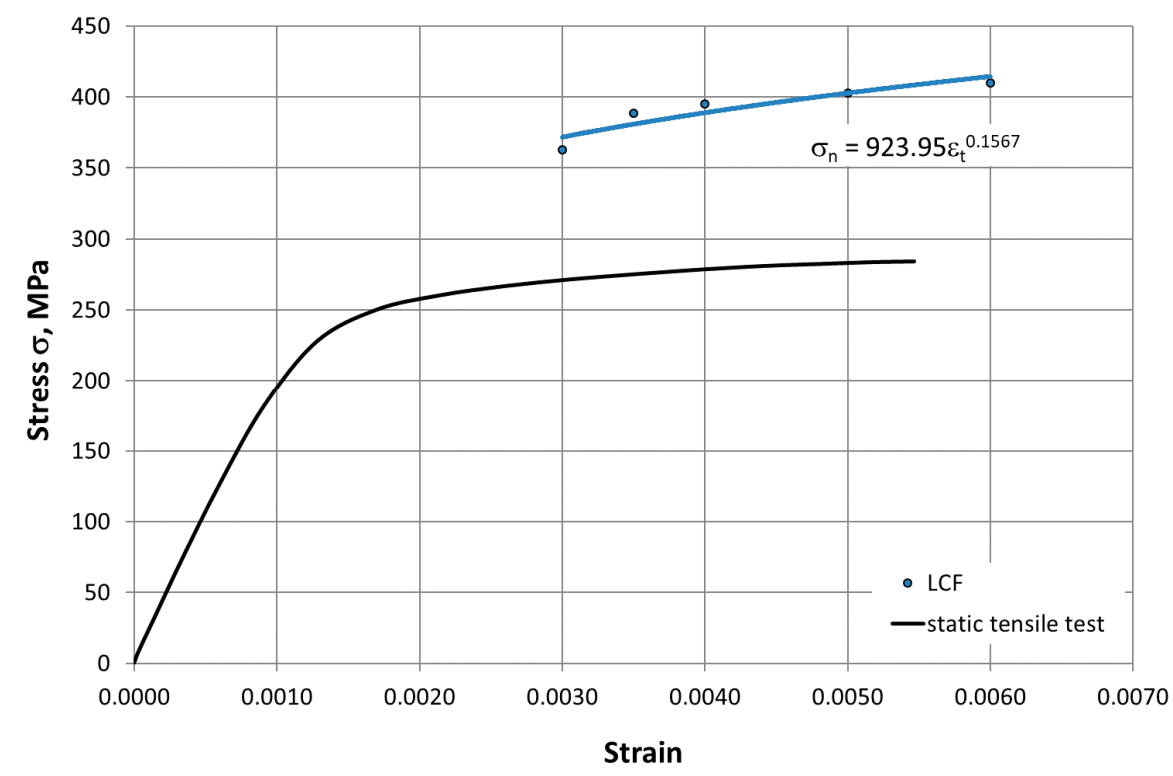

Figure 10. Cyclic strengthening curve for HR6W alloy at room temperature against a curve determined in a static tensile test (LCF_-Low Cycle Fatigue).

As can be seen from the comparison of the curves, the HR6W alloy under the fatigue test conditions was characterized by cyclic hardening both at room temperature and at $650{ }^{\circ} \mathrm{C}$. In addition, mathematical models of cyclic strengthening were developed by $\sigma_{\mathrm{an}}=\mathrm{K} / \cdot \varepsilon_{\mathrm{apl}}{ }^{\mathrm{n} \prime}$ (Figure 12), which were described by the expression, where $\mathrm{K}^{\prime}$-is the cyclic strength coefficient, and $\mathrm{n}^{\prime}$ - the cyclic weakening coefficient.

The analysis of the characteristics obtained indicates cyclic strengthening of the HR6W alloy both at room temperature and elevated temperatures. At $650{ }^{\circ} \mathrm{C}$, the strengthening process is significantly greater. A greater increase in the value of the stress $\sigma_{\text {an }}$ is visible with the increase in the amplitude of the strain $\varepsilon_{\text {apl }}$. In this case, the value of the cyclic strength coefficient $\mathrm{K}^{\prime}=1403.9 \mathrm{MPa}$ and the cyclic weakening coefficient $\mathrm{n}^{\prime}=0.1709$ are significantly higher than those determined for room temperature, i.e., $\mathrm{K}^{\prime}=717.62 \mathrm{MPa}$ and $\mathrm{n}^{\prime}=0.0992$ (Figure 12). The increase in stresses at room temperature from the initial state to 
the saturation state was found to be on average $80 \mathrm{MPa}$, while the temperature of $650{ }^{\circ} \mathrm{C}$ was on average $240 \mathrm{MPa}$.

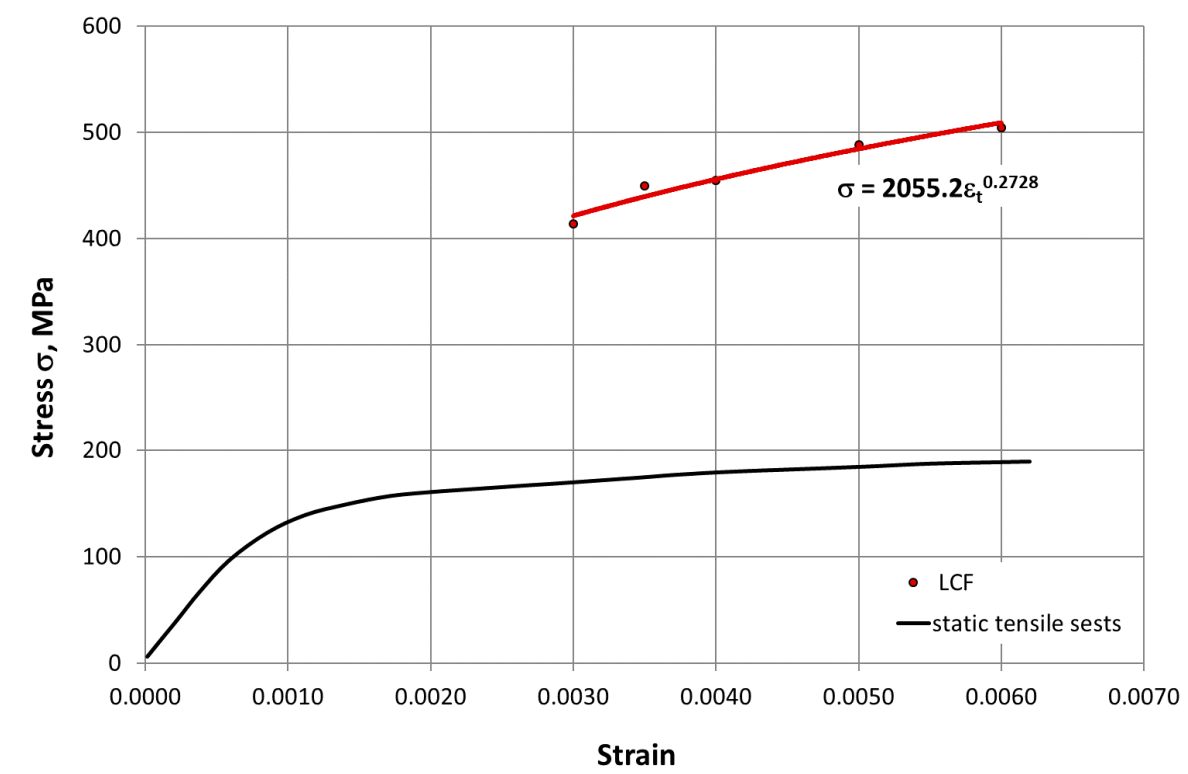

Figure 11. Cyclic strengthening curve for HR6W alloy at $650{ }^{\circ} \mathrm{C}$ against a curve determined in a static tensile test (LCF-Low Cycle Fatigue).

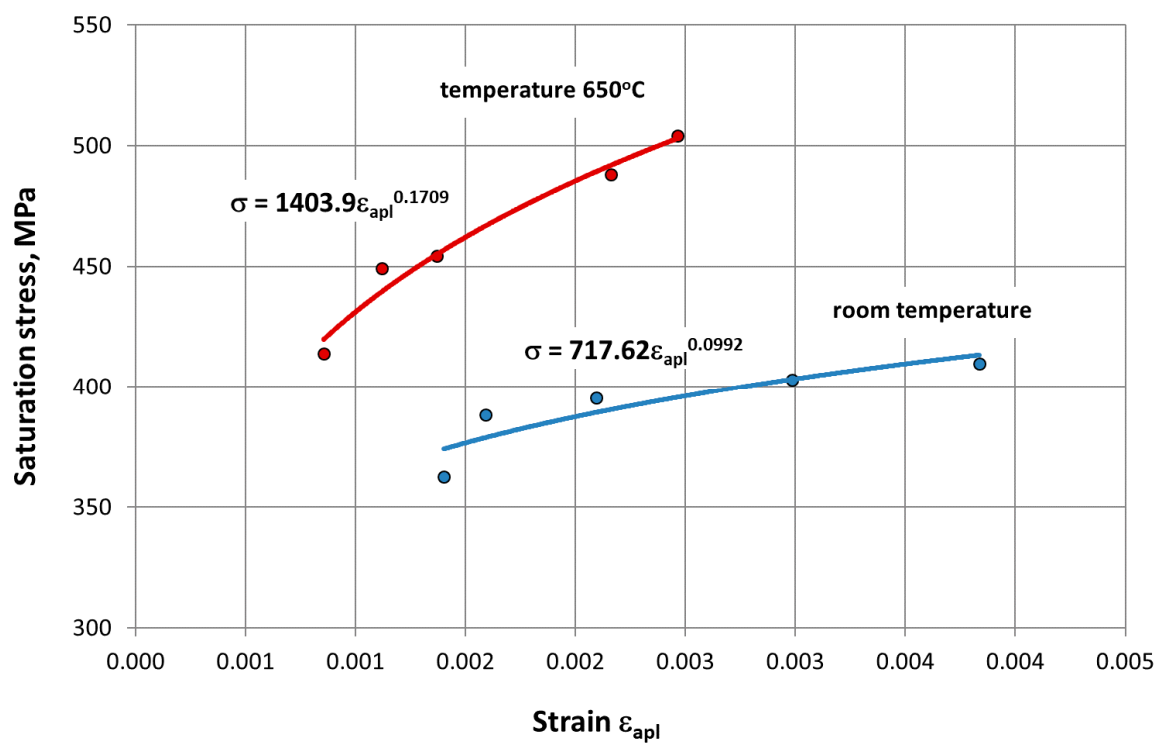

Figure 12. Cyclic strengthening curves for HR6W alloy at room temperature and $650{ }^{\circ} \mathrm{C}$.

Evidence for a much higher intensity of strengthening at $650{ }^{\circ} \mathrm{C}$ can also be seen in the characteristics of cyclic deformation (Figures 13 and 14). The process is particularly dynamic in the initial phases of LCF tests, which was observed for all ranges of total strain. The effect observed here is analogous to the characteristics shown in Figures 10 and 11. 


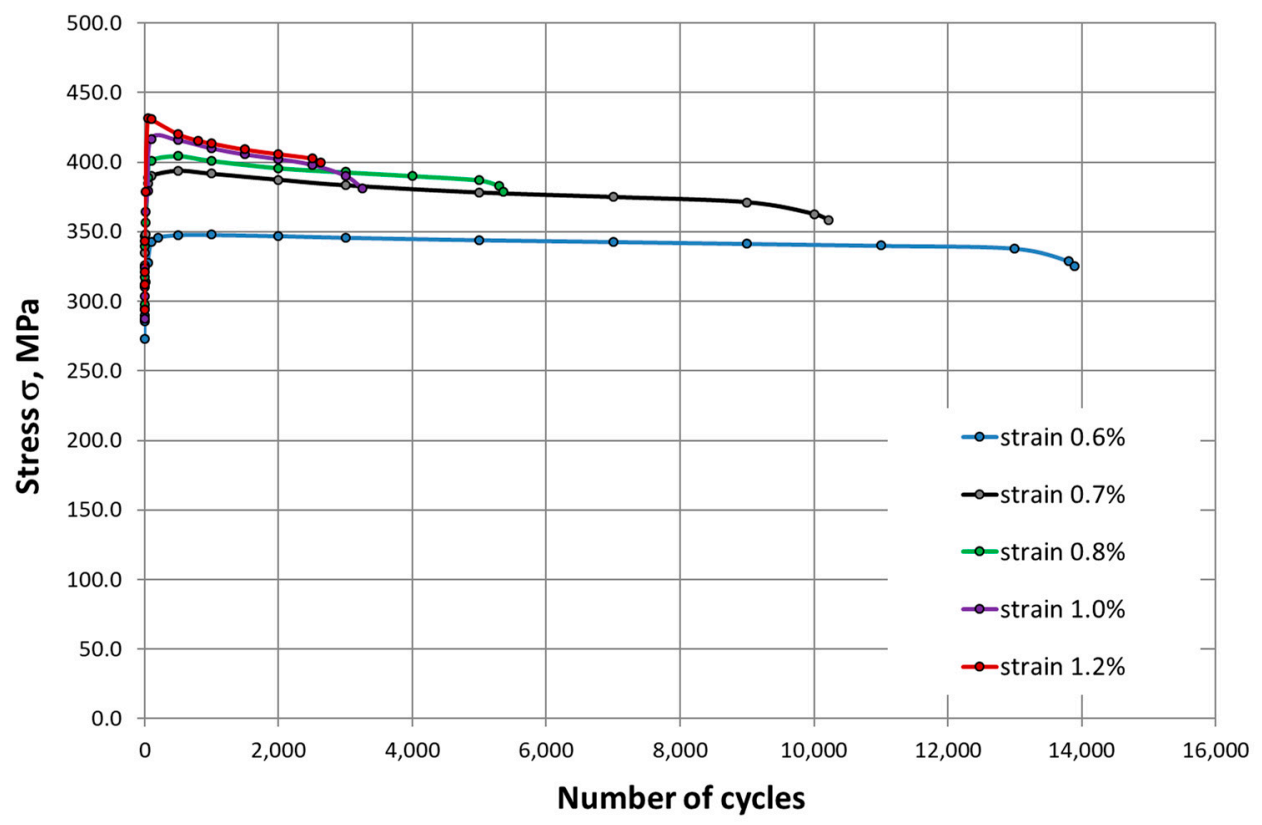

Figure 13. Evolutions of the stress range of HR6W at room temperature.

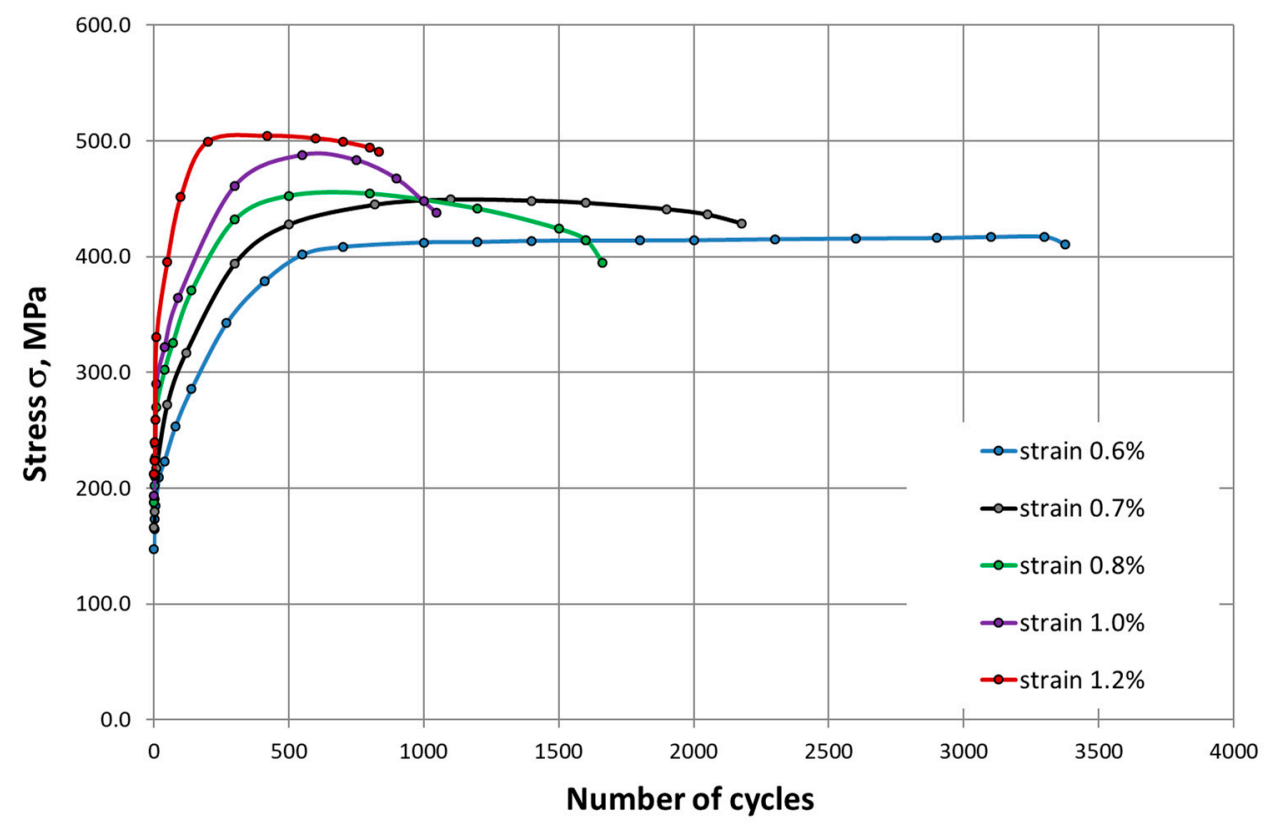

Figure 14. Evolutions of the stress range of $\mathrm{HR} 6 \mathrm{~W}$ at $650{ }^{\circ} \mathrm{C}$.

Based on the results obtained (Tables 2 and 3), Figure 15 summarizes values for fatigue life $\mathrm{N}_{\mathrm{f}}$ versus total strain range $\Delta \varepsilon_{\mathrm{t}}$.

From the analysis of the data, it can be concluded that, at room temperature, a strainrange $\left(\Delta \varepsilon_{\mathrm{t}}\right)$ dependent fatigue life $\mathrm{N}_{\mathrm{f}}$ of the HR6W alloy increased several times (from approx. 3 to approx. 4 ) as compared to its durability at $650{ }^{\circ} \mathrm{C}$. On the other hand, when analyzing the results of testing the material at $650{ }^{\circ} \mathrm{C}$, it can be noticed that, with a double increase in the total strain range $\Delta \varepsilon_{\mathrm{t}}$, for example from $0.6 \%$ to $1.2 \%$, the number of cycles to failure $\mathrm{N}_{\mathrm{f}}$ decreased four times from 3377 to 834 , and at room temperature up to four times from 13,890 to 2630 . 


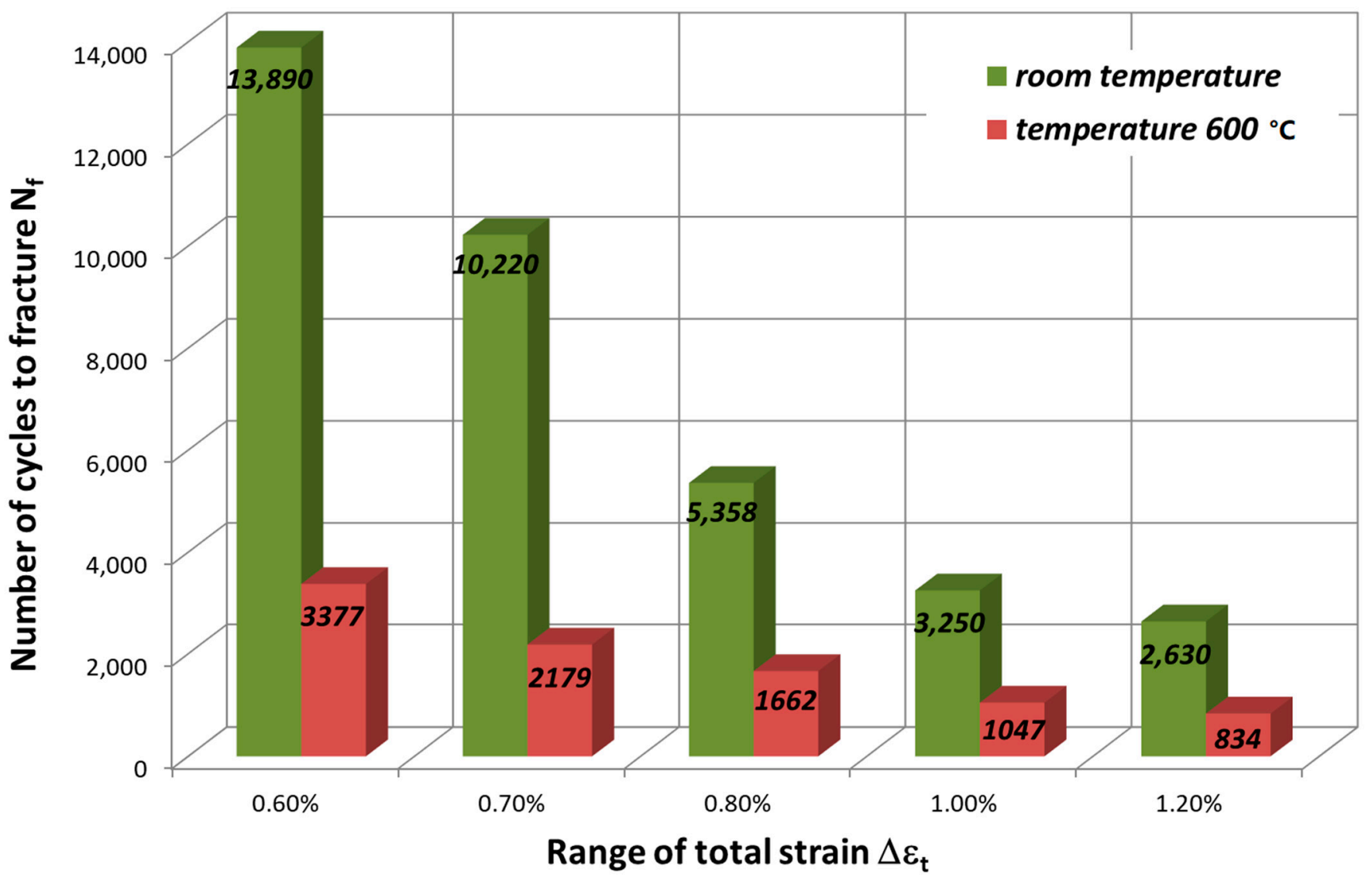

Figure 15. Low-cycle fatigue life $\mathrm{N}_{\mathrm{f}}$ for HR6W alloy at room temperature and $650{ }^{\circ} \mathrm{C}$.

Based on the mechanical characteristics in Tables 2 and 3, the fatigue life graphs for HR6W were also developed (Figures 16 and 17) according to the equation given by Manson-Coffin:

$$
\Delta \varepsilon_{\mathrm{t}}=\Delta \varepsilon_{\mathrm{pl}}+\Delta \varepsilon_{\mathrm{el}}=\mathrm{M} \cdot \mathrm{N}_{\mathrm{f}}^{\mathrm{Z}}+\frac{\mathrm{G}}{\mathrm{E}} \cdot \mathrm{N}_{\mathrm{f}}^{v}
$$

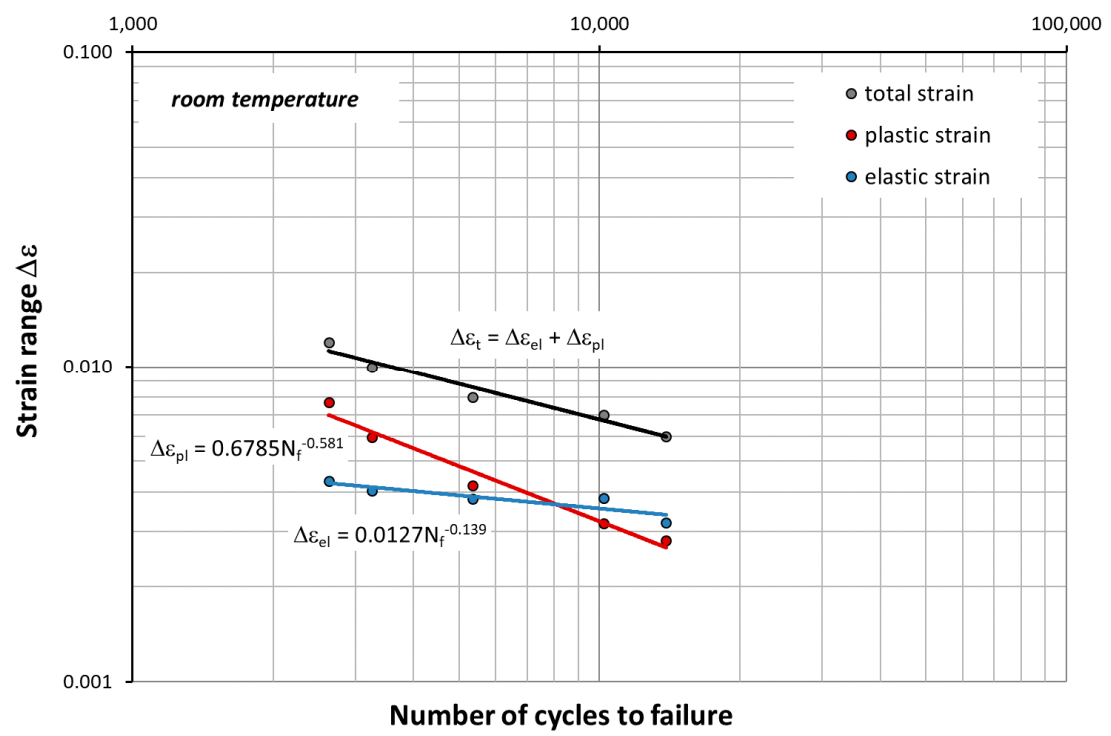

Figure 16. Range strain $\Delta \varepsilon$ versus the number of cycles to failure $\mathrm{N}_{\mathrm{f}}$ at room temperature described by Formula (1). 


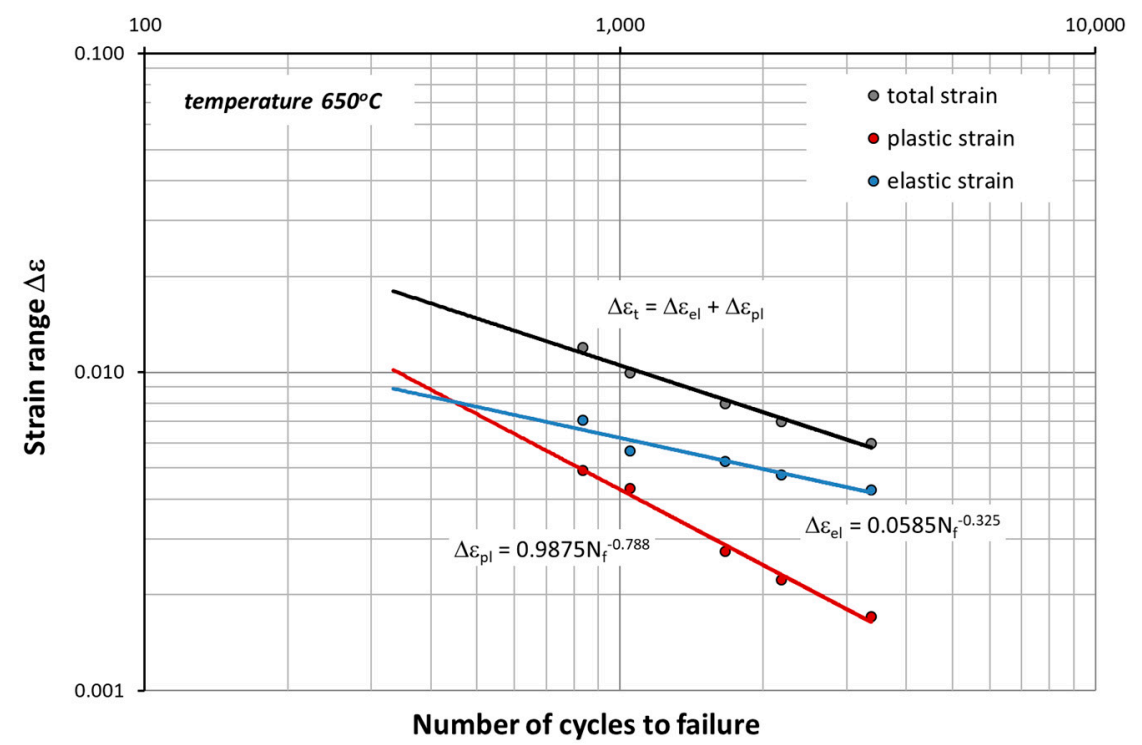

Figure 17. Range strain $\Delta \varepsilon$ versus the number of cycles to failure $\mathrm{N}_{\mathrm{f}}$ at $650^{\circ} \mathrm{C}$ described by Formula (1).

At elevated temperature $\left(650^{\circ} \mathrm{C}\right)$, as shown in Figure 17, in the process of cyclic strain, the elastic component of strain $\Delta \varepsilon_{\mathrm{el}}$ is dominant. In this case, strain is accompanied by higher stress $\sigma_{\text {an }}$ compared to that occurring at room temperature (Figures 10-12). On the other hand, as shown in Figure 11, at room temperature, the cyclic strain occurs with the dominant plastic strain component $\Delta \varepsilon_{\mathrm{pl}}$. Therefore, it can be assumed that cyclic strain resistance depends mainly on plastic properties.

\section{Conclusions}

On the basis of the results obtained in low-cycle fatigue testing at room temperature and at $650{ }^{\circ} \mathrm{C}$, the following conclusions were formulated:

1. The low-cycle fatigue (LCF) life of HR6W at room temperature, expressed as the number of cycles $\left(\mathrm{N}_{\mathrm{f}}\right)$ to fracture, increased several times as compared with its fatigue life at the temperature of $650{ }^{\circ} \mathrm{C}$, depending on the strain range $\Delta \varepsilon_{t}$ used in the fatigue tests. The increase is approximately three fold with a greater strain range $\left(\Delta \varepsilon_{\mathrm{t}}=1.0 \div\right.$ $1.2 \%)$ and approximately four fold with a smaller stain range $\left(\Delta \varepsilon_{t}=0.6 \div 0.8 \%\right)$ used in the fatigue tests.

2. Under low-cycle fatigue (LCF) conditions at $650{ }^{\circ} \mathrm{C}$, the fatigue life of $\mathrm{HR} 6 \mathrm{~W}$ alloy decreased approximately four times from $\mathrm{N}_{\mathrm{f}}=3377$ to 834 cycles, with a double increase in the total strain range from $\Delta \varepsilon_{\mathrm{t}}=0.6 \%$ to $1.2 \%$. On the other hand, at room temperature, the tests showed an approximately 5 -fold reduction in fatigue life from $\mathrm{N}_{\mathrm{f}}=13,890$ to 2630 cycles, with a similar increase in total strain range $\Delta \varepsilon_{\mathrm{t}}$.

3. HR6W alloy shows cyclical strengthening both at room temperature and $650{ }^{\circ} \mathrm{C}$. At elevated temperature, strengthening is significantly greater. It is characterized by a greater increase in stress values $\sigma_{\text {an }}$ along the decrease in strain amplitude $\varepsilon_{\text {apl }}$. In this case, the value of the cyclic strength factor $\mathrm{K}^{\prime}=1403.9 \mathrm{MPa}$ and the cyclic strengthening factor $\mathrm{n}^{\prime}=0.1709$ are significantly higher than those determined for room temperature $\left(\mathrm{K}^{\prime}=717.62 \mathrm{MPa}\right.$ and $\mathrm{n}^{\prime}=0.0992$, respectively).

4. Analyzing the results of the research on the fatigue of the low-cycle HR6W alloy at the temperature of $650{ }^{\circ} \mathrm{C}$, the process of cyclic hardening of the HR6W alloy is clearly visible. Such behavior of this material is mainly related to the processes of precipitation strengthening taking place in its structure at the boundaries of its grains, in the form of carbides $\mathrm{M}_{23} \mathrm{C}_{6}$.

Author Contributions: Conceptualization, G.J. and A.M.; methodology, G.J. and A.M.; formal analysis, A.M. and M.P.; investigation G.J. and A.M.; resources, A.M.; writing—original draft preparation, 
M.P. and A.M.; writing—review and editing, G.J., A.M. and M.P.; visualization, G.J. and M.P.; All authors have read and agreed to the published version of the manuscript.

Funding: In this paper results of tests financed by the Ministry of Science and Higher Education under the project BK-231/RM3/2021.

Institutional Review Board Statement: Not applicable.

Informed Consent Statement: Not applicable.

Data Availability Statement: Data are contained within the article.

Conflicts of Interest: The authors declare no conflict of interest.

\section{References}

1. Abe, F. Development of creep-resistant steels and alloys for use in power plants. In Structural Alloys for Power Plants Operational Challenges and High-Temperature Materials; Shirzadi, A., Jackson, S., Eds.; Woodhead Publishing Series in Energy; Woodhead Publishing: Sawston, UK, 2014; pp. 250-293. [CrossRef]

2. Hernas, H.; Dobrzański, J.; Pasternak, J.; Fudali, S. Charakterystyki Nowej Generacji Materiatów dla Energetyki; Wydawnictwo Politechniki Śląskiej: Gliwice, Poland, 2015. (In Polish)

3. Yin, Y.; Faulkner, R.; Starr, F. Austenitic steels and alloys for power plants. In Structural Alloys for Power Plants; Shirzadi, A., Jackson, S., Eds.; Woodhead Publishing: Sawston, UK, 2014; pp. 107-152. [CrossRef]

4. $\quad$ Chenga, L.-Y.; Wanga, R.-Z.; Wanga, J.; Zhub, S.-P.; Zhaoa, P.-C.; Miurac, H.; Zhanga, X.-C.; Tua, S.-T. Cycle-dependent creepfatigue deformation and life predictions in a nickel-based superalloy at elevated temperature. Int. J. Mech. Sci. 2021, $206,106628$. [CrossRef]

5. Gianfrancesco, A.D. New Japanese Materials for A-USC Power Plants Materials for Ultra-Supercritical and Advanced Ultra-Supercritical Power Plants; Woodhead Publishing: Sawston, UK, 2017; pp. 423-468. [CrossRef]

6. Okrajni, J.; Twardawa, M.; Mutwil, K.; Junak, G. Badania wytrzymałości i trwałości elementów rurociagów energetycznych. In Maszyny i Urządzenia Energetyczne Węglowych Bloków na Wysokie Parametry Pary; Chmielniak, T., Rusin, A., Eds.; Wydawnictwo Politechniki Śląskiej: Gliwice, Poland, 2015; pp. 374-492. (In Polish)

7. Abe, F. Research and Development of Heat-Resistant Materials for Advanced USC Power Plants with Steam Temperatures of $700{ }^{\circ} \mathrm{C}$ and Above. Engineering 2015, 1, 211-224. [CrossRef]

8. Metzger, K.; Czychon, K.-H.; Zickler, S.; Maile, K. Experience with the Operation of a -RIG for $700{ }^{\circ} \mathrm{C}$ Power Plant Materials. Procedia Eng. 2013, 55, 470-473. [CrossRef]

9. Semba, H.; Okada, H.; Yonemura, M.; Igarashi, M. Creep Strength and Microstructure in 23Cr-45Ni-7W Alloy (HR6W) and Ni-base Superalloys for Advanced. In Proceedings of the 34th MPA-Seminar Materials and Components Behaviour in Energy \& Plant Technology, Stuttgart, Germany, 9-10 October 2008.

10. Cempura, G.; Rutkowski, B.; Rydel, J.J.; Cieszyński, K.; Czyrska-Filemonowicz, A. Microstructural evolution of HR6W alloy during ageing at high temperature. Inżynieria Mater. 2016, 5, 211-216. [CrossRef]

11. Tokairin, T.; Dahl, K.V.; Danielsen, H.K.; Grumsen, F.B.; Sato, T.; Hald, J. Investigation on long-term creep rupture properties and microstructure stability of Fe-Ni based alloy Ni-23Cr-7W at $700{ }^{\circ} \mathrm{C}$. Mater. Sci. Eng. A 2013, 565, 285-291. [CrossRef]

12. Iwamaru, A.; Hisazawa, H.; Terada, Y. Microstructure Evolution of Fe-Ni-Based Alloy HR6W during Isothermal Aging. Mater. Trans. 2019, 60, 824-829. [CrossRef]

13. Cui, S.; Zhang, Z.; Xu, Y.; Li, J.; Xiao, X.; Zhu, C. Improvement of Stress-rupture Life for Modified-HR6W Austenitic Stainless Steel. J. Mater. Sci. Technol. 2011, 27, 1059-1064. [CrossRef]

14. Jinga, H.; Luoa, Z.; Xua, L.; Zhaoa, L.; Hana, Y. Low cycle fatigue behavior and microstructure evolution of a novel 9Cr-3W-3Co tempered martensitic steel at $650^{\circ} \mathrm{C}$. Mater. Sci. Eng. A 2018, 731, 394-402. [CrossRef]

15. Azeeza, A.; Erikssona, R.; Calmunger, M. Characterisation of deformation and damage in a steam turbine steel subjected to low cycle fatigue. Procedia Struct. Integr. 2019, 23, 155-160. [CrossRef]

16. León-Cázares, F.D.; Monni, F.; Jackson, T.; Galindo-Nava, E.I.; Rae, C.M.F. Stress response and microstructural evolution of nickel-based superalloys during low cycle fatigue: Physics-based modelling of cyclic hardening and softening. Int. J. Plast. 2020, 128, 102682. [CrossRef]

17. Viswanathana, R.; Colemana, K.; Raob, U. Materials for ultra-supercritical coal-fired power plant boilers. Int. J. Press. Vessel. Pip. 2006, 83, 778-783. [CrossRef]

18. Zhang, T.; Wang, X.; Ji, Y.; Tang, J.; Jiang, Y.; Zhang, X.; Gong, J. Cyclic deformation and damage mechanisms of $9 \%$ Cr steel under hybrid stress-strain controlled creep fatigue interaction loadings. Int. J. Fatigue 2021, 151, 1-14. [CrossRef]

19. Turka, A.; Bombac, D.; Rydel, J.J.; Ziętara, M.; Rivera-Díaz-del-Castillo, P.E.J.; Galindo-Nava, E.I. Grain boundary carbides as hydrogen diffusion barrier in a Fe-Ni alloy: A thermal desorption and modelling study. Mater. Des. 2018, 160, 985-998. [CrossRef]

20. Noguchi, Y.; Okada, H.; Semba, H.; Yoshizawa, M. Isothermal, Thermo-Mechanical and Bithermal Fatigue Life of Ni Base Alloy HR6W for Piping in $700{ }^{\circ} \mathrm{C}$ USC Power Plants. Procedia Eng. 2011, 10, 1127-1132. [CrossRef] 
21. Yin, P.; Zhang, W.; Guo, S.; Wen, J.; Zhang, G.; Xue, F.; Zhao, Y.; Zhou, C. Thermomechanical fatigue behaviour and damage mechanisms in a 9\% Cr steel: Effect of strain rate. Mater. Sci. Eng. A 2021, 815, 141308. [CrossRef]

22. Gong, X.; Wang, T.; Li, Q.; Liu, Y.; Zhang, H.; Zhang, W.; Wang, Q.; Wang, Q. Cyclic responses and microstructure sensitivity of Cr-based turbine steel under different strain ratios in low cycle fatigue regime. Mater. Des. 2021, 201, 109529. [CrossRef] 